\title{
MATHEMATICS TOOLS DEVELOPMENT BASED ON WEB WITH MOODLE APPLICATIONS IN BASED STATISTICS SUBJECT
}

\author{
Rina Dwi S, Febrian Dewanto, Bagus Ardi S
}

This research is the development of learning tools, which aims to: (1) describe the development of tools and produce mathematics learning application based on WEB with MOODLE Application On valid Based Statistics Subject. (2) To determine Effectiveley results the tools of learning. Moreover, the learning tools to be developed are the whole Syllabus, lesson plans, and text book learning. Those tools are developed by using the development model of 4D thiagdarajan Field trials conducted an web learning course on Education Statistics experiments Class, in this study were 36 students at class $3 \mathrm{~A}$, while the control class is 35 students of 3B class. Independent variables are motivation and activity, while the dependent variable is the learning achievement. Data taken with the deployment of questionnaires, observation and tests. Data processed with comparisons t test and regression.

The results the influence of motivation and activity of learning achievement of $89.7 \% \mathrm{~d}$ ) and the average of learning achievement experimental class achieve exhaustiveness $74.25 \mathrm{e}$ ) Average learning achievement of experimental class 74.25 , better than average learning achievement for control class 64.57. Based on the research results obtained are valid learning tools and effective learning that show the development of learning tools goals achieved.

Keywords: Development Learning Tools, WEB, MOODLE 


\section{PENDAHULUAN}

Undang-Undang No 20 Tahun 2003 pasal 50 ayat (3) tentang pemerintah dan/atau pemerintah daerah menyelenggarakan sekurang-kurangnya satu satuan pendidikan pada semua jenjang pendidikan untuk dikembangkan menjadi satuan pendidikan bertaraf internasional. Dengan muncul banyak sekolah yang bertaraf international maka perlu disiapkan tenaga kependidikan yang handal dan berjatidiri. IKIP PGRI Semarang merupakan satu-satunya perguruan swasta di Jawa Tengah yang ditugaskan oleh pemerintah untuk menyiapkan guru-guru RSBI melalui program pendidikan guru matematika dan ilmu pengetahuan alam bertaraf internasional (PGMIPABI) serta menjadi pusat pengembangan pendidikan ramah anak, bekerjasamadengan SIDA( Swedish International Development Cooperation Agency) dan Lund University Swedia (ikippgrismg.ac.id,2012).

Pembelajaran E-learning sudah ada di IKIP PGRI Semarang namun masih belum maksimal dalam pemanfaatannya. Pemilihan media pembelajaran yang sesuai dengan perkembangan saat ini dan disesuaikan dengan psikologi mahasiswa merupakan pilihan yang tepat oleh seoarang pengajar untuk meningkatkan prestasi mahasiswa. Sejalan dengan perkembangan ICT, media dengan menggunakan teknologi memang dapat dijadikan pilihan untuk menerapkan konsep dalam proses pembelajaran. E-Learning atau Electronic learning adalah sebuah konsep dalam proses pembelajaran dengan menggunakan ICT, khususnya menggunakan media yang berbasis internet (Darmayanti, 2007:101). Perlu diuji coba pembelajaran dengan website dengan menggunakan aplikasi Modular Object Oriented Dynamic Learning Environment (MOODLE) yang berisi semua hal tentang perkuliahan. Maka penelitian ini mengambil tema "Pengembangan Perangkat Pembelajaran Berbasis Web Menggunakan Aplikasi MOODLE Matakuliah Statistika Dasar". 


\section{MASALAH}

Berdasarkan latar belakang masalah di atas, maka dapat dirumuskan beberapa permasalahan, antara lain sebagai berikut.

1. Bagaimanakah mengembangkan perangkat pembelajaran berbasis web menggunaka aplikasi MOODLE matakuliah Statistika Dasar?

2. Apakah pembelajaran pembelajaran berbasis web menggunaka aplikasi MOODLE matakuliah Statistika Pendidikan efektif? 


\section{TUJUAN}

Tujuan yang ingin dicapai melalui penelitian ini adalah sebagai berikut:

1. Menghasilkan perangkat pembelajaran berbasis web menggunakan aplikasi MOODLE yang valid.

2. Mengahasilkan pembelajaran pembelajaran berbasis web menggunaka aplikasi MOODLE matakuliah Statistika Pendidikan efektif. 


\section{LANDASAN TEORI}

\section{MOODLE (Modular Object Oriented Dynamic Learning Environment).}

Dalam situs resminya (www.moodle.org), adalah sebuah nama untuk sebuah program aplikasi yang dapat merubah sebuah media pembelajaran kedalam bentuk web. Aplikasi ini memungkinkan siswa untuk masuk kedalam "ruang kelas" digital untuk mengakses materimateri pembelajaran. Dengan menggunakan Moodle, kita dapat membuat materi pembelajaran, kuis, jurnal elektronik dan lain-lain. Moodle itu sendiri adalah singkatan dari Modular Object Oriented Dynamic Learning Environment.

Moodle merupakan sebuah aplikasi Learning Management System (LMS) yang gratis dapat di-download, digunakan ataupun dimodifikasi oleh siapa saja dengan lisensi secara GNU (General Public License). Anda dapat mendownload aplikasi Moodle di alamat http://www.moodle.org. yang dikembangkan oleh Martin Dougiamas. Saat ini Moodle sudah digunakan pada lebih dari 150.000 institusi di lebih dari 160 negara di dunia. Beberapa keunggulan dan yang kita dapatkan dari membangun e-learning dengan menggunakan Moodle sebagai berikut: (a) Sederhana, efisien, ringan dan kompatibel dengan banyak browser; (b) Mudah cara instalasinya serta mendukung banyak bahasa, termasuk Indonesia; (c); Tersedianya manajemen situs untuk pengaturan situs keseluruhan, mengubah theme, menambah module, dan sebagainya; (d) Tersedianya manajemen pengguna; (e) Manajemen kursus, penambahan jenis kur sus, pengurangan, atau pengubahan kursus; (f) Modul Chat, modul pemilihan (polling), modul forum, modul untuk jurnal, modul untuk kuis, modul untuk survai dan workshop, dan masih banyak lainnya; (g) Free dan open source software.

Ini sejalan dengan kebijakan pemerintah dengan IGOS-nya, Moodle bersifat free dan open source. Oleh karena itu, Moodle sesuai digunakan di lingkungan pendidikan. Di samping itu, Moodle bisa dimodifikasi dan disesuaikan dengan kultur yang ada di Indonesia.

\section{Pembelajaran Berbasis Web dengan aplikasi MOODLE}

Khan (1997) mendefinisikan pembelajaran berbasis web (WBL) sebagai program pengajaran berbasis hypermedia yang memanfaatkan atribut dan sumber daya World Wide Web (Web) untuk menciptakan lingkungan belajar yang kondusif. Sedangkan menurut Clark (1996), WBL adalah pembelajaran individual yang dikirim melalui jaringan komputer umum atau pribadi dan ditampilkan oleh web browser. Oleh karena itu kemajuan WBL akan terkait dengan kemajuan teknologi web (perangkat keras dan perangkat lunak) maupun pertumbuhan jumlah situs-situs web di dunia yang sangat cepat.

Dengan digunakan web based learning dalam pembelajaran, beberapa aktifitas yang dapat dilakukan antara lain adalah : (a) Mancari informasi (buku-buku, bibliografi, ensiklopedi, program, dan lain-lain); (b) Distribusi materi edukasi (teks, program);(c) enyediakan kurikulum dan panduan belajar serta latihan dalam format yang diinginkan, seperti hypertext, audio, video;

(d) Membentuk aktifitas-aktifitas kolaborasi (diskusi kelompok melalui e-mail dan mailing list);

(e) Tanya jawab; (f) Tutorial, simulasi. Jadi web based learning adalah suatu sistem belajar jarak jauh berbasis teknologi informasi dengan antarmuka web. 


\section{METODE PENELITIAN}

\section{Jenis Penelitian}

Sesuai dengan tujuan penelitian, maka penelitian ini tergolong dalam penelitian pengembangan. Perangkat yang dikembangkan dalam penelitian ini meliputi: (a) silabus, (b) RPP ,(c) Bahan ajar. Instrumen penelitian meliputi: (a) lembar validasi silabus, (b) lembar validasi RPP, (c) lembar validasi Bahan ajar digital, (d) lembar validasi tes prestasi belajar, (e) lembar pengamatan keterampilan memecahkan masalah mahasiswa, dan (f) lembar validasi angket motivasi mahasiswa

\section{Populasi dan sampel}

Populasi penelitian ini adalah mahasiswa semester 3 IKIP PGRI Semarang progdi Pend. Matematika, dan sampelnya adalah kelas 3A (kelas eksperimen), 3B(kelas kontrol), 3C(kelas uji coba).

\section{Uji lapangan}

a. Analisis lapangan sebelum uji coba

Uraian pelaksanaan uji coba adalah sebagai berikut: perangkat pembelajaran di lapangan bertujuan untuk memperoleh data atau masukan dari guru, peserta didik dan para pengamat (observer) terhadap semua perangkat pembelajaran yang telah disusun sebagai dasar untuk melakukan revisi (penyempurnaan) perangkat pembelajaran dan instumen lembar observasi. Rancangan, subjek, pelaksanaan dan tujuan uji coba perangkat pembelajaran ini dijelaskan secara singkat sebagai berikut.

\section{Teknik Pengumpulan Data}

Teknik pengumpulan data yang digunakan menggunakan metode: (a) Metode Dokumentasi; (b) Metode Tes; (c) Metode Observasi; (d) Metode Angket

\section{Teknik Analisis Data}

a. Analisis Data Awal

a) Analisis penentuan kelas eksperimen dan kelas kontrol dari data nilai tes matematika semester gasal. Selanjutnya Uji Normalitas dan Uji Homogenitas dan Uji Kesamaan Ratarata

b. Analisis Data Untuk Merevisi Perangkat Tes

Sebagai dasar untuk merevisi perangkat tes draft II menjadi draft III (draft final) dalam penelitian ini akan dilakukan: (a) analisis validitas butir soal, (b) analisis reliabilitas perangkat tes, (c) analisis tingkat kesukaran, dan (d) daya beda butir soal.

c. Analisis Data Akhir

1) Perangkat pembelajaran valid berdasarkan uji coba lapangan yang menghasilkan pembelajaran yang efektif.

a) Prestasi belajar peserta didik mencapai ketuntasan yang diinginkan.

b) Berpengaruhnya aktivitas peserta didik terhadap prestasi belajar peserta didik

c) Prestasi belajar kelas eksperimen dibanding kelas kontrol 


\section{HASIL PENELITIAN}

\section{Hasil Penelitian}

\section{a. Proses Pengembangan Perangkat}

Pada bagian ini akan dipaparkan tahapan-tahapan pada pengembangan perangkat pembelajaran matematika berbasis WEB dengan aplikasi MOODLE menggunakan modifikasi teori Thiagarajan.

\section{1)Tahap Pendefinisian}

\section{(a) Analisis ujung-depan}

Perangkat pembelajaran merupakan komponen penting penentu keberhasilan peserta didik dalam mempelajari suatu materi. Dalam penelitian ini, perangkat pembelajaran dikembangkan berpedoman pada kompetensi umum dari matakuliah Statistika Dasar, yaitu setelah mengikuti matakuliah ini mahasiswa dapat mengunakan konsep dalam Statistika Dasar untuk menyelesaikan masalah yang terkait dengan data statistik dalam kehidupan sehari-hari.

\section{(b) Analisis Peserta didik}

Karakteristik mahasiswa IKIP PGRI Semarang sekarang sudah banyak yang mengikuti perkembangan teknologi. Dengan adanya pembelajaran yang dilaksanakan secara on line mahasiswa memerlukan kemandirian yang lebih dalam mempelajari materi. Kemandirian harus tumbuh dikarenakan mereka harus belajar mandiri dan minim dalam mendapatkan perkuliahan tatap muka. Sehingga keberhasilan mendapatkan prestasi belajar yang tinggi juga sangat tergantung pada motivasi dan kemampuan dari mahasiswa sendiri.

\section{(c) Analisis Materi}

Pada penelitian ini diberikan delapan bahan ajar, oleh karena itu dilihat pula kesinambungan antara bahan ajar dengan variabel-variabel yang diinginkan. Seperti yang telah dijelaskan sebelumnya, materi akan disajikan dengan menghubungkan dengan pekerjaan mahasiswa sehari-hari sebagai guru. Materi yang diberikan disertai dengan contoh soal dan latihan yang memancing kemadirian mahasiswa. Selain itu materi yang tersaji diharapkan dapat meningkatkan prestasi belajar, motivasi dan aktivitas.

\section{(d) Analisis Tugas}

Analisis tugas adalah kegiatan pengidentifikasian keterampilan-keterampilan utama yang diperlukan dalam pembelajaran yang sesuai dengan SK dan KD berdasarkan pada analisis materi. Dalam hal ini akan dikembangkan 3 tugas yang akan dikirim pada pertemuan ke 3, 5 dan 7. Tugas yang diberikan memancing mahasiswa untuk mandiri mencari sumber atau referensi serta mandiri dalam menjawab pertanyaan. Dalam hal ini, tugas yang diberikan tidak hanya mengetahui kemampuan mahasiswa mengenai materi, tetapi juga memberikan tantangan kepada mahasiswa untuk lebih terampil menggunakan komputer dan internet. Misalnya saja mahasiswa diminta mencari referensi tambahan di internet, jawaban harus diketik (tidak tulis tangan) dan mengirimkan jawaban kepada tutor melalui email.

\section{(e) Merumuskan Tujuan Pembelajaran Khusus}

Analisis ini merupakan perumusan tujuan pembelajaran khusus yaitu indikator berdasarkan tujuan pembelajaran dalam RPP(Renacana Pelaksanaan Pembelajaran), dan penjabarannya 
berdasarkan hasil analisis materi/topik dan analisis tugas yang telah ditetapkan. Setelah mempelajari mata kuliah ini mahasiswa diharapkan dapat menggunakan konsep dalam Statistika Dasar untuk menyelesaikan masalah yang terkait dengan data statistik. Sedangkan tujuan secara khusus tersaji dalam RPP untuk setiap pertemuan.

\section{b. Tahap Perancangan}

\section{(1) Penyusunan Tes}

Dasar dari penyusunan tes ini adalah analisis tugas dan analisis materi yang dijabarkan dalam spesifikasi tujuan pembelajaran. Tes prestasi belajar diberikan berupa pilihan ganda yang akan disesuai dengan tujuan dan indikator yang telah ditetapkan dalam kisi-kisi tes prestasi belajar.

\section{(2) Pemilihan Media}

Proses pemilihan media disesuaikan dengan analisis tugas, analisis materi dan karakteristik peserta didik. Media yang digunakan adalah WEB menggunakan aplikasi MOODLE. E-learning dipilih karena dianggap tepat bagi mahasiswa pada pendidikan tinggi jarak jauh yang mempunyai kendala ruang dan waktu dengan memanfaatkan teknologi. Jika dihubungkan dengan teori Gagne, sistem E-learning menggunakan $W E B$ termasuk ke dalam kategori belajar kognitif strategi. Dimana teori ini lebih menitik beratkan pada self learner yang dilakukan tanpa tatap muka langsung dengan pendidik. Hal ini dapat meningkatkan kemandirian mahasiswa dalam mengeksplore materi lebih banyak lagi dengan penggunaan internet yang ada.

\section{(3) Pemilihan Format}

Dalam pemilihan format perangkat pembelajaran berpedoman pada pedoman di IKIP PGRI Semarang yang menggunakan WEB dengan aplikasi MOODLE.

\section{(4) Desain Awal Perangkat Pembelajaran}

Kegiatan ini merupakan penulisan perangkat pembelajaran, yang meliputi: Silabus, RPP, Bahan ajar.

\section{c. Tahap Pengembangan}

\section{(1) Validasi Ahli}

Penilaian ahli meliputi validasi produk, yaitu mencakup semua perangkat pembelajaran yang dikembangkan pada tahap perancangan. Validasi dilakukan oleh 5 orang yang berkompeten untuk menilai kelayakan perangkat pembelajaran. Diantaranya adalah Achmad Buchori, S.Pd., M.Pd., Budi Cahyono, S.Pd., M.Si., Wijayanto, S.Si, M.Kom.

\section{(2) Ujicoba pengembangan}

Ujicoba pengembangan terdiri dari ujicoba perangkat pembelajaran dan ujicoba prestasi belajar. Hasil dari ujicoba ini akan dibahas pada bagian selanjutnya 


\section{Hasil Validasi}

Validasi ahli dilakukan pada perangkat pembelajaran, angket motivasi dan lembar pengamatan Aktivitas. Silabus 3,9, RPP 3,6, Bahan ajar 3,7, motivasi 3,7 dan aktivitas 3,9 jadi rata-rata keseluruhan 3,7 .

\section{Hasil Uji Coba Tes Prestasi Belajar}

Uji validitas, reabilitas, tingkat kesukaran dan daya beda soal dilakukan untuk mengetahui kelayakan soal. Uji Validitas Butir Soal dicari juga apakah soal itu valid (layak digunakan) atau tidak valid. Berikut adalah Tabel tentang validitas soal dengan membandingkan $r_{x y}$ dengan $\mathrm{r}$ Tabel. Jumlah yang valid adalah 29 soal, uji reabilitas soal dilakukan menggunakan rumus alpha menghasilkan nilai $\quad r_{11}=0,874$, uji daya beda angka yang menunjukkan besarnya daya pembeda disebut dengan indeks diskriminasi. Dengan kriteria penentuan jenis daya beda yaitu jelek 1, cukup 16, baik 13 dan baik sekali 0 , Uji tingkat kesukaran butir soal menghasilkan perhitungan jumlah peserta didik yang berhasil seperti pada tingkat sukar 6 soal, sedang, 16 dan mudah 8 .

\section{Hasil Angket dan Lembar Pengamatan}

Untuk motivasi sebelum disebarkan, instrumen divalidasi oleh kelima validator dengan ratarata penilaian sebesar 3,7 dengan nilai reliabilitas sebesar 0,710. Tingkat kepuasaan mahasiswa mendapatkan persentase paling tinggi yaitu sebesar $29 \%$ untuk pernyataan sangat setuju dan $41 \%$ untuk peryataan setuju. Sedangkan untuk kondisi perhatian mendapatkan skor $16 \%$ untuk skor tidak setuju dan $8 \%$ untuk pernyataan tidak setuju. Sedangkan aktivitas, lembar pengamatan aktivitas terdiri dari 5 butir dan diamati oleh dua orang pengamat. aktivitas mahasiswa dalam menerjemahkan kedalam masalah matematika mendapatkan skor 5 sebanyak $69 \%$.

\section{Hasil Uji Coba Lapangan}

Hasil ujicoba lapangan dilakukan untuk mengetahui apakah pembelajaran dengan menggunakan perangkat pembelajaran matematika berbasis aplikasi efektif. Hasil ujicoba lapangan diolah dengan menggunakan SPSS 16.

\section{Uji normalitas dan Uji Homogenitas}

Sebelum dilakukan uji apakah pengembangan perangkat pembelajaran efektif maka akan dilakukan uji normalitas dan homogenitas terlebih dahulu. Dengan melihat nilai Standar Error Mean sebesar 0,461 merupakan nilai yang dekat dengan nol (0). Ini menunjukkan bahwa rataan merupakan penaksir yang baik terhadap rataan populasi. Dengan melihat nilai skewness sebesar

0,475 dekat dengan nol dan gambar histogtam serta kurva normalnya mengarah pada data berdistribusi normal. Keputusan ini diperkuat dengan memakai uji kolmogorov smirnov untuk uji normalitas, dengan nilai sig $=0,07$ atau sekitar $7 \%$. Nilai tersebut lebih besar dari $5 \%$ berarti bahwa distribusi variabel adalah normal.

Untuk selanjutnya dilakukan uji homogenitas dengan hasil sebagai berikut. Dengan melihat output statistic untuk uji homogenitas terlihat bahwa nilai kurtosis sebesar -0,12 menunjukkan 
nilai negatif jadi data cenderung tumpul, akan tetapi nilai tersebut tidak jauh dari nol jadi bisa dikatakan data cenderung homogen.

\section{Pengaruh Motivasi dan Aktivitas terhadap Prestasi Belajar}

Selain mencari pegaruh variabel dependen (motivasi dan Aktivitas) terhadap prestasi belajar satuu per satu, peneliti juga mencari pengaruh motivasi dan Aktivitas secara bersamasama dengan menggunakan uji statistik regresi linier ganda. Dari output Coefficients untuk Uji Pengaruh Motivasi dan Aktivitasdiperoleh nilai $\mathrm{a}=-90.291, \mathrm{~b}=0.122$ dan $\mathrm{c}=1.447$ sehinga didapat persamaan regresi $\mathrm{y}=-90.291+0.122 \mathrm{x}_{1}+1.447 \mathrm{x}_{2}$. Dengan melihat Tabel ANOVA, diperolah nilai $\mathrm{Sig}=.000=0 \%<5 \%$. Dari nilai yang didapat maka $\mathrm{H}_{0}$ ditolak yang berarti motivasi dan Aktivitasberpengaruh terhadap prestasi belajar.

Nilai koefisien determinasi dapat dilihat pada nilai R Square pada Tabel Model Summary didapat $0,897=89,7 \%$. Nilai tersebut menunjukkan bahwa motivasi dan Aktivitas mempengaruhi prestasi belajar sebesar $89,7 \%$.

\section{Prestasi Belajar Mencapai Kriteria Ketuntasan Minimal.}

Hasil dari analisis data mengenai hasil prestasi belajar mahasiswa mencapai ketuntasan minimal tersaji menggunakan SPSS One-Sample Test untuk Uji Ketuntasan. Seperti yang sudah dijelaskan pada bab sebelumnya bahwa prestasi belajar dikatakan tuntas jika memenuhi syarat ketuntasan belajar yaitu jika rata-rata skor prestasi belajar mencapai sekurang-kurangnya 70 . Melalui analisis Compare means, one sample T test dengan bantuan SPSS 16 diperoleh nilai sig adalah 0,034 atau 3,4\%. Dari hasil tersebut terlihat bahwa $\mathrm{H}_{0}$ ditolak sehingga rata-rata nilai tes prestasi belajar tidak sama dengan 70 .

Penyelidikan lebih lanjut melihat rataan empiris pada Tabel 4.23 output one-sample statistics untuk uji ketuntasan terlihat bahwa rata-rata nilai prestasi belajar sebesar 74,25. Nilai tersebut menunjukkan rata-rata nilai tes lebih dari kriteria ketuntasan sehingga dapat disimpulkan prestasi belajar tuntas.

\section{Prestasi Belajar Kelas Eksperimen Lebih Baik Dibandingkan Kelas Kontrol}

Dengan melihat nilai sig pada Tabel Indipendent Samples Test sebesar 0,101=10,1\%. Nilai sig tersebut lebih besar dari $5 \%$ maka $\mathrm{H}_{0}$ diterima, maka tidak terdapat perbedaan varians antara kelas uji coba perangkat dan kelas kontrol atau kedua kelas homogen.

Informasi tersebut digunakan untuk melakukan uji selanjutnya yaitu uji banding t. Selanjutnya dengan melihat nilai pada kolom sig (2-tailed) kolom Independent sample t-test sebesar 0,019 < 0,05 menunjukkan bahwa $\mathrm{H}_{0}$ di tolak, artinya prestasi belajar kelas uji coba dan kelas kontrol berbeda signifikan. Dengan melihat rata-rata prestasi belajar pada kolom mean, Tabel Group Statistics diperoleh 74,25 untuk kelas eksperimen dan 64,37 untuk kelas kontrol. Hasil tersebut menunjukan bahwa prestasi belajar kelas eksperiman lebih baik dibandingkan dengan kelas kontrol. 


\section{PEMBAHASAN}

\section{Validasi}

Perangkat yang dikembangkan dalam penelitian ini ada 4 jenis yaitu : Silabus, RPP, Bahan ajar. Proses pengembangan perangkat dimulai dengan menyusun draft awal yang dilanjutkan oleh proses validasi. Berdasarkan hasil revisi dari validator diperoleh draft II yang selanjutnya diujicobakan. Selama proses ujicoba, dilakukan revisi-revisi perangkat sesuai dengan tuntutan lapangan atau masukan dari pihak luar sehingga diperoleh draft III. Pembahasan hasil pengembangan perangkat pembelajaran antara lain sebagai berikut.

a) Validasi terhadap Silabus

Silabus merupakan rencana program kegiatan perkuliahan untuk satu matakuliah diambil delapan kali pertemuan dalam satu semester yang digunakan sebagai pedoman untuk menyusun rencana kegiatan setiap sesi/pertemuan. Karena merupakan rancangan untuk seluruh pertemuan maka Silabus diharapkan memperhatikan karakterisitik mahasiswa, materi dan metode yang diberikan. Pada umumnya validator memberikan penilaian yang cukup baik untuk Silabus yang telah dibuat yaitu sebesar 3,9. Hal tersebut dikarenakan ketidaktelitian penulisan dan ketidakjelasan bahasa yang digunakan pada penulisan Silabus.

b) Validasi terhadap RPP

RPP merupakan rencana kegiatan untuk setiap kali pertemuan yang memberikan petunjuk secara rinci tentang proses pembelajaran yang dilakukan dalam RPP. Skor rata-rata RPP yang diberikan validator sebesar 3,6. Dari 20 terdapat 3 indikator medapatkan nilai 3 dari kelima validator, salahsatunya indikatornya adalah "RPP yang dikembangkan memenuhi unsur penerapan MOODLE". Menurut salah satu validator unsur aplikasi MOODLE tidak tampak pada RPP sebelumnya.

c) Validasi terhadap Bahan ajar

Bahan ajar merupakan kegiatan pembelajaran online yang berupa bacaan yang diperuntukkan kepada mahasiswa untuk menambah pengetahuan (pengayaan materi) dan tidak memerlukan umpan balik (feedback) dari mahasiswa. Pada penelitian bahan ajar dibuat dengan menggunakan flash dengan latihan interaktif. Hal tersebut dilakukan agar mahasiswa dapat mempelajari latihan dan diberikan feedback secara langsung. Selain itu latihan yang diberikan dalam bahan ajar dapat menuntun mahasiswa untuk mengerjakan soal yang diberikan.

d) Validasi terhadap Tugas

Tugas diberikan untuk mengetahui sejauh mana mahasiswa memahami materi yang diberikan. Menurut validator soal dalam tugas kurang berbobot sehingga harus diperbaiki kualitas soalnya. Sama seperti perangkat yang dibahas sebelumnya bahwa dalam tugas unsur aplikasi kurang tampak. Hal tersebut dapat terlihat dari nilai yang diberikan validator sebesar 3,6.

e) Validasi terhadap Angket Motivasi

Secara keseluruhan angket motivasi sudah baik. Validator menyarankan agar identitas tidak ditampilkan agar pengisi angket merasa leluasa mengisi angket tersebut. Selain itu bahasa yang digunakan sebaiknya diperbaiki agar tidak membingungkan pengisi angket. Kedua masukan tersebut sudah ditindaklanjuti. 


\section{f) Validasi terhadap Lembar Pengamatan Aktivitas}

Menurut salah satu validator menyatakan aktivitas merupakan keterampilan yang dilakukan melalui pengamatan, oleh karena itu lembar pengamatan harus benar-benar dapat menjadi acuan untuk mengamati keterampilan tersebut. Salah satu yang harus diperbaiki adalah bahasa yang digunakan dalam lembar pengamatan.

\section{Ujicoba Tes Prestasi Belajar}

Sebelum ujicoba lapangan, terlebih dahulu dilakukan uji coba intrumen tes hasil belajar kognitif untuk mengetahui kualitas instrumen yang meliputi validitas item, reliabilitas instrumen, daya pembeda soal, dan tingkat kesukaran butir soal. Uji coba instrumen dilakukan kelas 3A, dengan pertimbangan peserta didik telah menerima materi yang diujikan.

Hasil uji validitas terdapat 2 soal yang tidak valid yaitu no 7 dan 8 . Soal tersebut tidak valid dikarenakan mempunyai nilai 0,24 yang kurang dari nilai $\mathrm{r}_{\text {Tabel }}$. Pada uji reabilitas soal dari data analisis instrumen diperoleh nilai alpha sebesar 0,836 , artinya instrumen reliabel dan mempunyai reliabilitas sangat tinggi. Daya beda diapat hasil 1 soal yang mempunyai daya beda jelek yaitu no 20 yang mempunyai indeks diskriminasi 0 sehingga soal harus dibuang atau tidak dipakai. Dan uji tingkat kesukaran terrlihat bahwa tingkat kesukaran dari soal yang telah diujicobakan beragam terdapat 8 butir soal yang mudah, 16 butir soal yang sedang dan 6 butir soal yang dianggap sukar. Dari data tersebut dapat disimpulkan bahwa soal yang diberikan baik, karena terdapat beragam tingkat kesukaran.

\section{Angket dan Lembar Pengamatan}

Pada motivasi persentase instrumen motivasi terlihat lebih dari 50\% mahasiswa memberikan pernyataan setuju dan sangat setuju. Sedangkan kurang dari 25\% mahasiswa menjawab pernyataan tidak setuju dan sangat tidak setuju. Dengan memperhatikan lampiran 13 ternyata sebagian besar mahasiswa memberikan jawaban tidak setuju dan sangat tidak setuju untuk instrumen yang mempunyai pernyataan negatif. Dan Untuk mengamati Aktivitas mahasiswa, pengamat mengamati aktivitas mahasiswa pada saat pembelajaran dengan web berjalan. Aktivitas, selain itu pengamat juga mengamati ketiga tugas yang dikerjakan mahasiswa. 


\section{Ujicoba Lapangan}

\section{Pengaruh Motivasi dan Aktivitas terhadap Prestasi Belajar}

Berdasarkan hasil uji pengaruh dengan menggunakan regresi ganda, menunjukkan bahwa motivasi dan Aktivitas mempengaruhi prestasi belajar sebesar 89,7\%. Sisanya dipengaruhi variabel lain.

\section{Prestasi Belajar Mencapai Kriteria Ketuntasan Minimal.}

Dari hasil uji banding untuk mencari ketuntasan prestasi belajar, didapat bahwa rata-rata nilai prestasi belajar sebesar 74,25 . Nilai tersebut menunjukkan rata-rata nilai tes lebih dari kriteria ketuntasan sehingga dapat disimpulkan prestasi belajar tuntas.

Dengan hasil dan proses yang dilakukan mahasiswa dalam mengikuti pembelajaran dengan aplikasi MOODLE yang baik, dapat disimpulkan bahwa perangkat pembelajaran dapat meningkatkan pencapaian rata-rata nilai prestasi belajar mahasiswa dalam mencapai standar ketuntasan.

\section{Prestasi Belajar Kelas Eksperimen Lebih Baik Dibandingkan Kelas Kontrol}

Setelah diketahui kedua kelas, didapat rata-rata prestasi belajar sebesar 74,25 untuk kelas eksperimen dan 64,37 untuk kelas kontrol. Hasil tersebut bebeda dengan hasil pretes yang dilakukan di awal pertemuan. Hasil penelitian menunjukkan bahwa perangkat pembelajaran berbasis aplikasi teknologi telah berhasil meningkatkan motivasi mahasiswa. hal tersebut mengakibatkan prestasi belajar kelas eksperimen lebih baik dibandingkan dengan kelas kontrol. Sehingga dapat ditarik kesimpulan bahwa pembelajaran dengan menggunakan hasil pengembangan perangkat pembelajaran berbasis WEB menggunakan aplikasi MOODLE matakuliah Statistika Dasar efektif. 


\section{DAFTAR PUSTAKA}

Chen, X. 2009. Design and Application of a General-purpose E-Learning Platform. International Journal of Business and Management. 4/9:178-181.

Darmayanti, T. 2007. E-learning pada Pendidikan Tinggi Jarak Jauh : Konsep yang mengubah metode pembelajaran di Perguruan Tinggi di Indonesia. Jurnal Pendidikan Terbuka dan Jarak Jauh, 8/2: 99-113.

Depdiknas. 2008. Pelatihan Kurikulum Tingkat Satuan Pendidikan (KTSP). Jakarta: Direktorat Jendral Manajemen Pendidikan Dasar dan Menengah.

Douigamas, Martin. Modular Object Oriented Dynamic Learning Environment. Dapat diakses di http://www.moodle.org

Guskey, T. 1982. The Effectiveness of Mastery Learning Strategies in Undergraduate Education Courses. New York.

Sudjana. 2002. Metoda Statistika. Bandung: Tarsito.

Sugiyono. 2009. Metode Penelitian Administrasi dilengkapi dengan Metode R\&D. Bandung: Alfabeta.

Thiagarajan, S., Semmel, D.S., \& Semmel, M.I. 1974. Instructional Development for Teachers of Exceptional Children. Minneapolis, Minnesota: Leadership Training Institute/Special Education, University of Minnesota. 
14 